DOI: https://doi.org/10.47405/mjssh.v6i6.829

\begin{tabular}{|c|c|}
\hline$x_{10}$ & Malaysian Journal of Social Sciences and Humanities (MJSSH) \\
\hline Malaysian Journal of & Volume 6, Issue 6, August 2021 \\
\hline $\begin{array}{l}\text { Humantures } \\
\text { (ms-sSH) }\end{array}$ & e-ISSN : 2504-8562 \\
\hline & $\begin{array}{l}\text { Journal home page: } \\
\text { www.msocialsciences.com }\end{array}$ \\
\hline
\end{tabular}

\title{
Assessment of Awareness and Behaviour Among Secondary School Students on Climate Change
}

\author{
Izzah Abd Hamid1, Wan Asrina Wan Yahaya1, Hairazi Rahim² \\ 1Department of Crop Science, Faculty of Agricultural Science and Forestry, Universiti Putra Malaysia Bintulu \\ Sarawak Campus, 97008 Bintulu, Sarawak, Malaysia \\ ${ }^{2}$ Socio Economic, Market Intelligence \& Agribusiness Research Center, MARDI Headquarters, Persiaran MARDI-UPM, \\ 43400 Serdang, Selangor, Malaysia
}

Correspondence: Wan Asrina Wan Yahaya (asrina@upm.edu.my)

\begin{abstract}
The climate change issue has been recognised as a global problem and it has to be given serious attention. The human contribution is necessary, it can be done through spreading awareness that will lead to behavioural changes. This study aims to assess the awareness and behaviour of secondary students and their contribution towards preventing climate change. The study was conducted with Nature Lovers and Peer Counsellors Club members at SMK Bandar Bintulu. About 133 surveys using Likert-scale with rating 1 to 4 were collected and analysed on frequency and percentage by SPSS. Findings revealed that the respondents' awareness of climate change occurs as they learn from the classroom and join the environmental related club. However, their awareness does not represent their behaviour in protecting climate change due to minimum exposure on the human contribution towards climate change. Therefore, this study, suggests a long-term campaign related to the effects of climate change on health, including proper education on rules and regulation implemented by authorities to cater for this situation.
\end{abstract}

Keywords: climate change, awareness, behavioural change, education, campaign

\section{Introduction}

Climate change has severe impacts on living creatures and the environment. It has been highlighted as a crucial topic discussed in mass media worldwide since the 21 st century. Many publications have focused on human contribution towards climate change that eventually will cause rising in global temperature and a widespread change in precipitation patterns and extreme weather such as heatwaves and large storms (Abdul Rahman, 2018; Kuok Ho, 2018). Humankind is considered the main contributor that has accelerated the climate change process through industrialisation and deforestation. This process never stops; hence, changes should be addressed carefully to reduce the impact by increasing awareness among the community. Other than that, further emphasis should be focused on the younger generations who are highly exposed to the issue, and they have opportunities to learn about climate change through mass media and comprehensive learning from school (Andersson and Öhman, 2017).

Spreading awareness is not the only main concern in protecting climate change since other factors while facilitating awareness should be spotlighted such as human behaviour. A few studies have been 
conducted in many countries to assess the level of awareness on climate change which could help human understanding and participate through changing their lifestyle. A study conducted by Pandve et al. (2011) has justified that awareness level in an urban community is higher compared to other locations. However, their awareness is based on their justification merely on their personal experience or knowledge. If the awareness based on their justification might not be significant and emotionally concerned, no action, or conative component arises. Nevertheless, some researchers believed that awareness might not be crucial in contributing to behaviour changes in protecting climate change. For example, they do not intend to play their role or participate (Bakar et al., 2013; Altin et al., 2014). However, a comprehensive campaign with proper education on climate change, including stricter rules and regulation implemented by authorities, could help to change their behaviour. For example, in India, changing climate change campaigns was done by focusing on a health-related campaign which led to behavioural changes and significantly enhanced awareness (Halady and Rao, 2010). Another study in Indonesia was conducted involving youth group in a facilitated educational campaign, which positively impacted and strengthened their understanding through an awareness program (Luthfia and Alkhajar, 2018), and slowly they changed their behaviour. A similar study was also performed on respondents taken an intensive university course on climate change. The respondents have exhibited changes in their attitudes and behaviour on protecting climate change after five years of taking the course (Cordero et al., 2020). The studies concluded that the effectiveness in changing youth behaviour could be found by educating them with an intensive campaign.

Awareness and behaviour changes should also be addressed on secondary students since their generation will become the leader and a successor in the future, which might affect climate change (Allen et al., 2013; Ojala and Lakew, 2017). The effort can be made by revising the education system to fill in the necessary information to enhance knowledge and awareness on climate change as Malaysia is classified as a developing country. Therefore, the objective of this study is to assess the awareness and behaviour of secondary students and their contribution towards preventing climate change.

\section{Methodology}

The study was undertaken in February 2020 in SMK Bandar Bintulu, Bintulu, Sarawak on the day of extension activities with the theme of Carbon Footprint involving Nature Lovers and Peer Counsellors Clubs members. About 150 survey form were distributed to the participant, and only 133 were returned with complete answers. The respondent' involvement was voluntary, and the survey was prepared in Bahasa Malaysia, which comprised of three sections; Section A (Demographic Information), Section B (Awareness with 13 items), and Section C (Behaviour with 10 items). Then, the questionnaire was then carefully translated into the English version. All items except Section A included a Likert scale with a scale of 1 to 4 to indicates strongly disagree (SD), disagree (D), agree (A), and strongly agree (SA).

Before the questionnaire was administered for this study, a pilot study was conducted among 20 students who helped distribute and collect these survey forms so that the researcher could verify the consistency and understanding of the questions. Any confusion on the questionnaire items was improvised and revised accordingly. All collected data were analysed in the Statistical Package for Social Sciences (SPSS) version 23.0 by using frequency and percentage on the occurrence of the data.

\section{Results and Discussion}

This study was conducted on 136 respondents, with $70.59 \%$ female students and $29.41 \%$ male students. The respondents' ages ranged from 13 to 17 years old, with the highest respondents from age 15 years old $(49.26 \%)$. Even though students studying in form 3 reported $50.74 \%$ compared to the percentage of the age 15, most of the students are classified as form 3 at the age of 15. Moreover, there is a higher percentage of student in form 3 due to their willingness to join the program and participate in this survey. 
DOI: https://doi.org/10.47405/mjssh.v6i6.829

Table 1: Respondent's demographic

\begin{tabular}{lll}
\hline Demography $(\mathbf{N}=136)$ & Frequency & Percentile (\%) \\
\hline Gender & & \\
$\quad$ Male & 40 & 29.41 \\
$\quad$ Female & 96 & 70.59 \\
Age & 5 & 3.68 \\
13 & 20 & 14.71 \\
14 & 67 & 49.26 \\
15 & 20 & 14.71 \\
16 & 24 & 17.65 \\
17 & & \\
Class/Form & 5 & 3.68 \\
1 & 19 & 13.97 \\
2 & 69 & 50.74 \\
3 & 18 & 13.24 \\
4 & 25 & 18.38 \\
5 & & \\
\hline
\end{tabular}

\section{Awareness of Climate Change}

Based on the results gathered from the finding, the respondents are aware of the signs of climate change $(66.91 \%)$, and $47.06 \%$ of respondents realise of melted ice phenomenon in the North Pole, $50.00 \%$ agreed that human and industrial activities are among the factors of climate change, and $62.50 \%$ agreed on natural disaster caused by climate change since it is frequently highlighted in the mass media. About $55.88 \%$ of respondents strongly agreed that temperature increase affects living organisms on earth as it affects their daily activities and health. Moreover, about $50.00 \%$ of respondents answered that they agreed that Malaysia's longer dry seasons is also a sign of climate change, and $47.79 \%$ chose that climate change has a long-term effect on human health and activities. Instead of respondents' awareness, their inquisitiveness in searching for information regarding climate change was also quantified. Accordingly, 55.88\% agreed that their knowledge exposure on the effect of climate change is mostly taken through mass media, and $48.53 \%$ actively find a solution to slow down the effects of climate change. About 55.88\% decided to spread the information with their family and friends and $57.35 \%$ agreed that sufficient information might slow down climate change. Additionally, $57.35 \%$ of respondent showed interest in helping or contributing to slow down the climate change process, and 52.94\% strongly agree with global climate change topics being taught in school.

Table 2: Respondent's awareness of climate change by percentile

\begin{tabular}{llllll}
\hline No. & Question & SD & D & A & SA \\
\hline 1 & $\begin{array}{l}\text { I know an increase in surrounding temperature is a sign } \\
\text { of climate change }\end{array}$ & 0.00 & 5.88 & 66.91 & 27.21 \\
2 & $\begin{array}{l}\text { I am aware that the melted ice phenomenon in the north } \\
\text { pole is a sign of increased temperature }\end{array}$ & 0.74 & 9.56 & 47.06 & 42.65 \\
3 & 2.21 & 13.24 & 50.00 & 34.56 \\
$\quad \begin{array}{l}\text { I know human activities such as agriculture and } \\
\text { industrialisation contribute to climate change }\end{array}$ & 2.94 & 19.12 & 62.50 & 15.44 \\
\hline $\begin{array}{l}\text { I know natural disaster like a tornado is an effect of } \\
\text { climate change }\end{array}$ & $\begin{array}{l}\text { I know increased temperature affects other living } \\
\text { organisms on earth }\end{array}$ & 0.74 & 6.62 & 36.76 & 55.88 \\
$6 \quad \begin{array}{l}\text { I know the long dry seasons is the effect of climate } \\
\text { change }\end{array}$ & 0.74 & 5.88 & 50.00 & 43.38 \\
7 & $\begin{array}{l}\text { I know climate change will have a long-term effect on } \\
\text { human health and activities }\end{array}$ & 1.47 & 5.88 & 47.79 & 44.85 \\
8 & $\begin{array}{l}\text { I always hear about the effect of climate change from } \\
\text { mass media }\end{array}$ & 1.47 & 8.82 & 55.88 & 33.82 \\
\hline
\end{tabular}


DOI: https://doi.org/10.47405/mjssh.v6i6.829

\begin{tabular}{llllll}
\hline 9 & $\begin{array}{l}\text { I always find a solution/way on how to slow down the } \\
\text { effect of climate change }\end{array}$ & 7.35 & 37.50 & 48.53 & 6.62 \\
10 & $\begin{array}{l}\text { I always share information about climate change with } \\
\text { family/friends }\end{array}$ & 2.94 & 24.26 & 55.88 & 16.91 \\
11 & $\begin{array}{l}\text { I believe awareness and proper information on climate } \\
\text { change will slow down this process }\end{array}$ & 2.94 & 21.32 & 51.47 & 24.26 \\
12 & $\begin{array}{l}\text { I am also interested in helping/contributing to slow down } \\
\text { the climate change process }\end{array}$ & 2.21 & 11.03 & 57.35 & 29.41 \\
13 & $\begin{array}{l}\text { I know issues on global climate change through science } \\
\text { and environmental subject in school }\end{array}$ & 0.74 & 2.21 & 44.12 & 52.94 \\
\hline
\end{tabular}

*SD-strongly disagree; D-disagree; A-agree; SA-strongly agree

Formal education has been successfully proven to increase awareness and knowledge among respondents regardless of their educational levels, which showed a comparable result to this study where $>50.00 \%$ awareness on climate change was reported. The respondents also provided evidence of their awareness of climate change since they consider the issue important to the country, especially when addressing global issues from rising water level to temperature since they are aware of basic climate change conditions. It was found that most of the respondents are a member of Nature Lovers and Peer Counsellors Clubs which is an added advantage to their tendency in creating more awareness and being thoughtful on climate change. The club is funded by a private agency that strives to protect the environment and frequently organises events to increase awareness as a part of its corporate social responsibility. Our findings are similar to previous researchers who emphasised the effect of formal education on raising awareness among secondary school students (Harker-Schuch and BuggeHenriksen, 2013; Ojala, 2015; Lekgeu and Davis, 2017). Through formal education, such as subject related to climate change, comprehensive education on climate change can be provided, which will significantly change the ways respondents react to climate change issues. Lekgeu and Davis (2017) and Ojala (2015) concluded that education is an explanatory factor that can influence or change a person's perception or attitude towards climate change. Their findings also demonstrated that most respondents only understand climate change, but they cannot react and prevent it from happening. It may be true as in this current study, in which the respondents only exhibited their awareness because of their comprehensive learning in class and community. It is hard to prove that they are practising environmental conservation to reduce climate change occurrence. Moreover, their exposure to the internet or mass media could positively contribute to increasing their awareness to prevent or slow down climate change but not their behaviour.

\section{Behaviours on Climate Change}

Awareness attributes among students may lead to climate change behaviour which the result has indicated that $43.38 \%$ agreed and $14.71 \%$ strongly agreed on using vehicles to move around. About $35.29 \%$ and $16.18 \%$ of respondents agreed and strongly agreed to use air-conditioner in their home. However, their answer is not consistent when only $53.68 \%$ of participants agreed on public transport as their mode of transportation. Meanwhile, $43.38 \%$ of samples agreed that they are using their vehicles to travel and move around. Apart from that, $42.65 \%$ agreed on using a bicycle as another sustainable method of transport. More than 50.00\% of respondents are not supportive of open burning when clearing litter, and they $(64.71 \%)$ strongly believed that open burning is not the best solution to dispose of trash. However, a few of them practice open burning near the agricultural area to supply burnt ash residue to increase soil fertility. About $61.03 \%$ agreed on their behaviour of cultivating crop around their house, including 55.88\% agreed on their contribution to fertilising their crop, and $41.91 \%$ of respondents agreed that they own livestock at their house. About $54.41 \%$ disagreed when responding to their tendency to helping their family clean or throwing crop residue in their surroundings.

Table 3: Respondent's behaviour on climate change by percentile

\begin{tabular}{llllll}
\hline No. & Question & SD & D & A & SA \\
\hline 1 & I always use a motorcycle/car to go to another place & 7.35 & 34.56 & 43.38 & 14.71 \\
2 & I always help my family to clear litter by open burning & 39.71 & 50.00 & 10.29 & 0.00 \\
\hline
\end{tabular}



DOI: https://doi.org/10.47405/mjssh.v6i6.829

\begin{tabular}{|c|c|c|c|c|c|}
\hline 3 & I always help my family to plant crop in house/farm & 0.74 & 13.97 & 61.03 & 24.26 \\
\hline 4 & $\begin{array}{l}\text { I always help my family to apply fertiliser more than crop } \\
\text { requirement in our house/farm }\end{array}$ & 2.94 & 22.79 & 55.88 & 18.38 \\
\hline 5 & I always use the air conditioner at home & 15.44 & 33.09 & 35.29 & 16.18 \\
\hline 6 & $\begin{array}{l}\text { I always help my family to clean/throw crop/tree around } \\
\text { the house/farm }\end{array}$ & 25.00 & 54.41 & 18.38 & 2.21 \\
\hline 7 & $\begin{array}{l}\text { I have a lot of livestock at my house/farm, which my } \\
\text { family owns }\end{array}$ & 13.97 & 36.03 & 41.91 & 8.09 \\
\hline 8 & $\begin{array}{l}\text { I fully support open burning as the best solution to } \\
\text { dispose of litter }\end{array}$ & 64.71 & 25.74 & 8.82 & 0.74 \\
\hline 9 & I always use a bicycle/walk to go to another place & 7.35 & 19.85 & 42.65 & 30.15 \\
\hline 10 & I always like to use public transport to go to another place & 5.15 & 16.18 & 53.68 & 25.00 \\
\hline
\end{tabular}

According to our findings, respondents' behaviour slightly changed when showing their concern in protecting climate change with minimal efforts, such as discouraging open burning that releases greenhouse gases such as carbon dioxide, methane, and particulate matters. Some respondents are using public transport and bicycle to go to other place or travel around the town. However, their effort is only limited to discouraging open burning, and in the meantime, they still use the air-conditioner. They are also taking care of livestock and using excessive fertiliser in their daily life. The respondents' behaviour in preventing climate change only happens when their awareness is significantly increased. However, in this study, their awareness is contradicted with their behaviour, which shows minimum effort to protect the climate even though they have a basic knowledge of climate change. These findings are similar to other researchers who reported the same results, such as in Universiti Putra Malaysia (UPM) context (Bakar et al., 2013) and formed four settings in Hulu Selangor, Malaysia (Damanhuri et al., 2016). A previous study on awareness and behaviour conducted by the researcher on zero-waste campaign yielded a similar finding. In contrast, a short-term campaign may create temporary awareness among respondents and, therefore, change their behaviour to a certain level before returning to support using plastic (Izzah and Wan Asrina, 2020). However, other factors need to be considered, such as respondents' backgrounds ranging from age, educational levels, household income, and locality (e.g., rural or urban areas). Early exposure by parent and society indeed can increase and change their behaviour. For example, in Kano State, Nigeria, respondents from rural areas display a willingness to be aware of climate change compared to sub-urban areas (Ali et al., 2017). The research contrasts to Pandve et al. (2011), who emphasised the effectiveness of preventing climate change by the urban community in Pune City, India. Nevertheless, the behaviour of respondents may continuously change if there is a prominent and long-term campaign on climate change awareness is taken seriously. India has practised this method by focusing on climate change impact on health, which has yielded promising results on changes in respondents' behaviour (Halady and Rao, 2010).

\section{Conclusion}

According to this study, more than $50 \%$ of respondents from secondary school have awareness of climate change, including a basic understanding of its signs. The awareness attributes can be gathered from formal education on the topic. However, the awareness remains only on the presence of climate change and not yet affecting their behaviour in preventing climate change. The study shows that the respondents are among contributing factor to climate change with the activities performed in their daily lives. However, some respondents are still concerned about human behaviours that will lead to climate change, such as open burning. This study would like to recommend prominent awareness by conducting a long-term campaign related to the effect of climate change on health, restricting the rules and regulation implemented by authorities, and providing relevant environmental education that may increase respondents' awareness which will lead to behavioural changes. 


\section{Acknowledgements}

We want to thank the Diploma in Agriculture and Diploma in Fisheries students who registered for Agricultural Extension (CES2241) courses in Universiti Putra Malaysia Bintulu Sarawak Campus, who helped distribute and collect surveys. Our appreciation also goes to all the respondents who supported and cooperated in this surveys and Madam Siti Fatimah Razali, who assisted with this documentation.

\section{References}

Abdul Rahman, H. (2018). Climate change scenarios in Malaysia: Engaging the public. International Journal of Malay-Nusantara Studies, 1: 55-77.

Ali, A. R., Endut, A., \& Embong, R. (2017). Investigating the environmental awareness level of secondary school students: Effects of race, school type, and location. Journal of Science and Technology, 9: 30-36.

Allen, M., Wicks, R., \& Schulte, S. (2013). Online environmental engagement among youth: Influence of parents, attitudes and demographics. Mass Communication \& Society, 16: 661-686.

Altin, A., Tecer, S., Tecer, L., Altin, S., \& Kahraman, B. F. (2014). Environmental awareness level of secondary school students: A case study in Balıkesir (Türkiye). Procedia-Social and Behavioral Sciences, 141: 1208-1214.

Andersson, E., \& Öhman, J. (2017). Young people's conversations about environmental and sustainability issues in social media. Environmental Education Research, 23: 465-485.

Bakar, H. A., Aziz, N. A., Narwawi, N. A. M., Latif, N. A., Ijas, N. M., \& Sharaai, A. H. (2013). kajian perhubungan antara kesedaran alam sekitar dengan tingkah laku mesra alam sekitar dalam kalangan pelajar universiti; Kajian kes: pelajar tahun satu Universiti Putra Malaysia (UPM). Journal of Chemical Information and Modeling, 53: 1689-1699.

Cordero, E. C., Centeno, D., \& Todd, A. M. (2020). The role of climate change education on individual lifetime carbon emissions. PloS One, 15: 1-23.

Damanhuri, M. I. M., Ehambron, D., \& Yusuf, M. (2016). Tahap kesedaran dan amalan pendidikan alam sekitar dalam kalangan pelajar Tingkatan 4 aliran sains di daearah Hulu Selangor. Geografi, 4: 28-35.

Halady, I., \& Rao, P. (2010). Does awareness to climate change lead to behavioral change? International Journal of Climate Change Strategies and Management, 2: 6-22.

Harker-Schuch, I., \& Bugge-Henriksen, C. (2013). Opinions and knowledge about climate change science in high school students. Ambio, 42: 755-66.

Izzah, A. H., \& Wan Asrina, W. Y. (2020). Zero-waste campaign: Assessment on university student's behaviour, awareness, and impact on plastic products. Malaysian Journal of Social Sciences and Humanities, 5: 24-29.

Kuok Ho, D. T. (2018). Climate change in Malaysia: Trends, contributors, impacts, mitigation and adaptations. Science of The Total Environment, 650: 1858-1871.

Lekgeu, M., \& Davis, N. (2017). Perceptions of climate change among Grade 11 learners in the Tshwane Metropolitan Municipality, South Africa. Southern African Journal of Environmental Education, 33: 52-70.

Luthfia, A., \& Alkhajar, E. (2018). Strengthening public awareness on climate change: Lesson learned from a youth social movement in Yogyakarta, Indonesia. IOP Conference Series: Earth and Environmental Science, 200: 1-7.

Ojala, M. (2015). Climate change skepticism among adolescents. Journal of Youth Studies, 18: 11351153.

Ojala, M., \& Lakew, Y. (2017). Young people and climate change communication. Oxford Research Encyclopedia of Climate Science, 1-30.

Pandve, H. T., Chawla, P. S., Fernandez, K., Singru, S. A., Khismatrao, D., \& Pawar, S. (2011). Assessment of awareness regarding climate change in an urban community. Indian Journal of Occupational and Environmental Medicine, 15: 109-112. 